\begin{tabular}{|c|c|c|c|c|c|c|}
\hline \multirow{4}{*}{ Impact Factor: } & ISRA (India) & $=3.117$ & SIS (USA) & $=0.912$ & ICV (Poland) & $=6.630$ \\
\hline & ISI (Dubai, UAE & $=0.829$ & РИНЦ (Russia) & ) $=\mathbf{0 . 1 5 6}$ & PIF (India) & $=1.940$ \\
\hline & GIF (Australia) & $=0.564$ & ESJI (KZ) & $=8.716$ & IBI (India) & $=4.260$ \\
\hline & JIF & $=1.500$ & SJIF (Morocco & $=5.667$ & OAJI (USA) & $=0.350$ \\
\hline
\end{tabular}

\begin{tabular}{|c|c|}
\hline $\begin{array}{l}\text { SOI: } \frac{1.1 / \mathrm{TA}}{\text { International Sc }} \\
\text { Theoretical } \boldsymbol{\&} \mathrm{A}\end{array}$ & $\begin{array}{l}\frac{\mathrm{S}}{\mathrm{DOI}} \mathrm{10.15863/ \textrm {TAS }} \\
\text { cientific Journal } \\
\text { Applied Science }\end{array}$ \\
\hline p-ISSN: 2308-4944 (print) & e-ISSN: 2409-0085 (online) \\
\hline Year: 2019 Issue: 03 & Volume: 71 \\
\hline Published: 30.03 .2019 & http://T-Science.org \\
\hline
\end{tabular}

SECTION 31. Economic research, finance, innovation, risk management.
QR - Issue

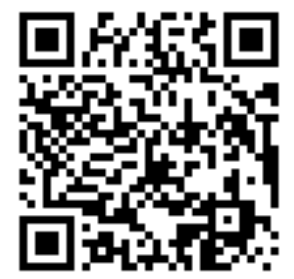

QR - Article

\title{
WAYS TO IMPROVE THE ACTIVITIES OF THE SYSTEM OF TAX MANAGEMENT AND ORGANIZATION OF THE WORK OF EMPLOYEES OF THE PUBLIC TAX SERVICE
}

Abstract: Role of management in further rationalizing and advancing of tax system of Republic Uzbekistan, comparative analysis of significant advancing in structural organization of administrative bodies of tax system between from the years of independence and nowadays, and information on calculation of average quantity of workload of employee of tax service in relative order was lightened up in this article. Of this order, the conclusions and proposals on advancing and development of experience and skills of employee of tax system were reflected in this article.

Key words: strategy of action, taxation system of the Republic of Uzbekistan, tax authorities, State Tax Committee, tax service employees, labor productivity, tax burden, taxpayers, individuals and legal entities.

Language: English

Citation: Tashmuhamedova, Y. A. (2019). Ways to improve the activities of the system of tax management and organization of the work of employees of the public tax service. ISJ Theoretical \& Applied Science, 03 (71), 538544.

Soi: http://s-o-i.org/1.1/TAS-03-71-53 Doi: crossef https://dx.doi.org/10.15863/TAS.2019.03.71.53

\section{Introduction}

Following the independence of the Republic of Uzbekistan, many reforms in economic, social, political and cultural spheres have been carried out in our country. Specific reforms in the tax system, such as laws and resolutions, as well as scientific and practical research, have been yielding good results.

Today, in the context of innovative development of the country's economy, the effective organization of tax services and further improvement of their taxation services is one of the most important tasks of improving the taxation mechanism in the republic.

The role of the State Tax Service plays an important role in addressing such important issues as collection of taxes, setting tax rates in line with public living standards, and taxpayers' knowledge of taxation and taxation.

\section{Literature review}

In this regard, many scientists have been carrying out their research since independence. Among them: Sh. Gataulin, S.G.Gulomov, L.V.Havan, Q.A.Yakhyoev [3], M.Sharifhodzhaev, T.Malikov, M.Allamardonov, A. Vakhobov [4], A.S.
Juraev [5], U.A.Radjabov, B.Isroilov, A.Mutalov, D.Mutalova, M.Kamilov, B.Sanakulova, O.Olimjonov, B.Toshmurodova, N.Kuziyeva, Sh.Toshmatov, O. Azizov and others. Aspects of small business taxes were studied by Ibragimov I., Tursunov B.O. [7-8] The results of these studies will help to further the country's economy, improve taxation and taxation, improve the living standards of the population, and form the knowledge of tax payers and tax payers.

\section{Analysis and results}

The first President of the Republic of Uzbekistan, IA Karimov, said: "The tax system, along with a clear targeted financial policy, redistributes part of the gross national product and thus directly participates in changing the structure of the economy and ensuring the social protection of the population."

Despite the fact that today's reforms in the tax system of the Republic of Uzbekistan have been successful, we can not say that the tax system is still fully developed, stable and problematic. 


\begin{tabular}{|c|c|c|c|c|c|c|}
\hline \multirow{4}{*}{ Impact Factor: } & ISRA (India) & $=3.117$ & SIS (USA) & $=0.912$ & ICV (Poland) & $=6.630$ \\
\hline & ISI (Dubai, UAE & $=0.829$ & РИНЦ (Russia) & $=0.156$ & PIF (India) & $=1.940$ \\
\hline & GIF (Australia) & $=0.564$ & ESJI (KZ) & $=8.716$ & IBI (India) & $=4.260$ \\
\hline & JIF & $=1.500$ & SJIF (Morocco) & $=5.667$ & OAJI (USA) & $=0.350$ \\
\hline
\end{tabular}

Therefore, scientific research on identification and elimination of existing problems in the tax system continues.

In the third priority direction of the "Development and liberalization of economy", defined by the President of the Republic of Uzbekistan Sh.M.Mirziyoev for the development of the country in the "Strategy of Action for the Development of the Republic of Uzbekistan in 2017-2021": further reduction of the tax burden, simplification of the taxation system and tax administration, the issues of improving the activities of tax authorities.[1,2]

The taxation system is, of course, the State Tax Committee. The State Tax Committee is the republican state body for control over observance of tax legislation, protection of economic interests and property rights of the state.

At present, the structure of the central apparatus of the State Tax Committee, the regional State Tax Administrations, and the State Tax Inspectorate in cities and districts are being improved. In particular, we can compare the structure of the tax administration service, from the years of independence to today, and see the process of change and development of the tax authorities.

In 2000 the structure of the State Tax Committee of the Republic of Uzbekistan was as follows:

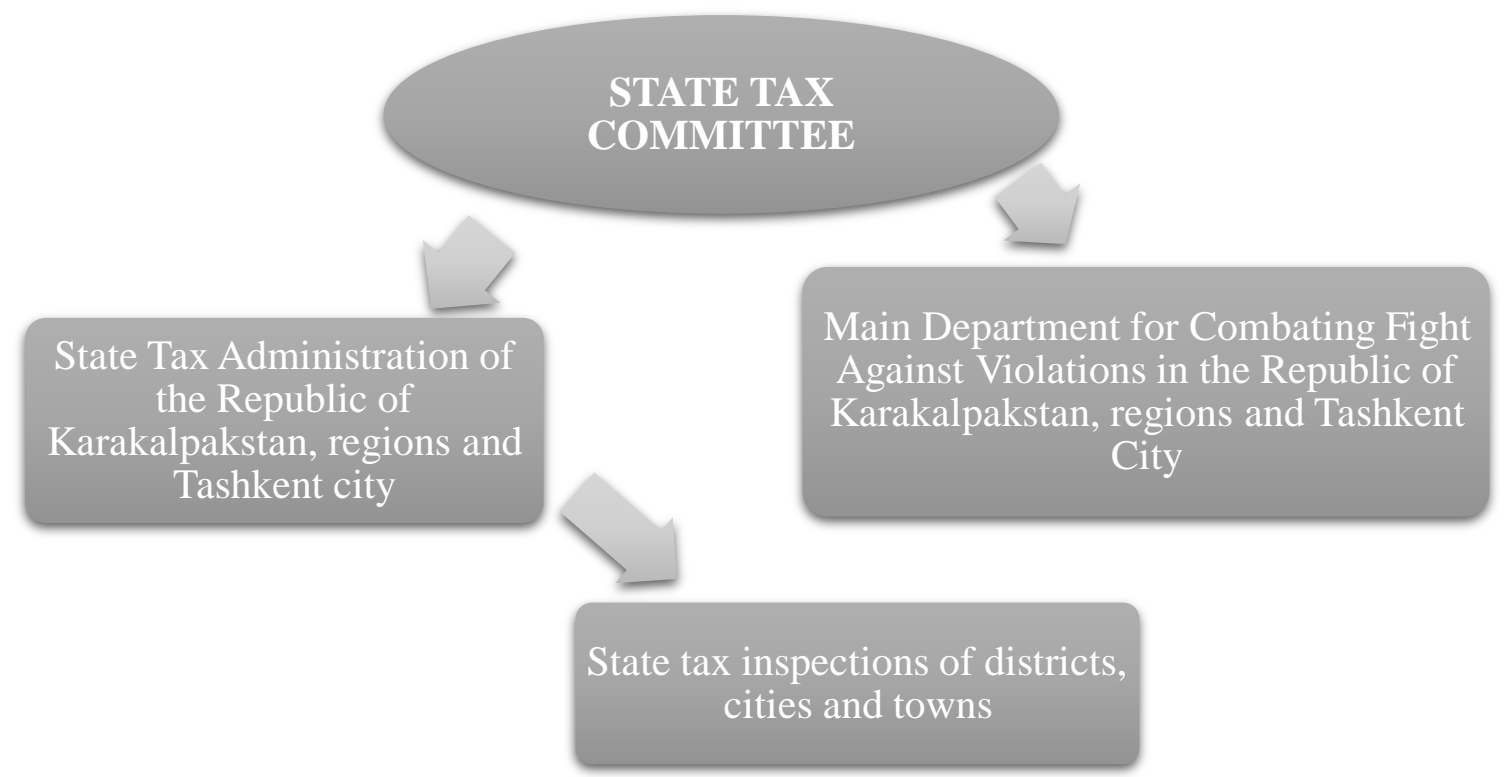

Fig. 1. Structure of the State Tax Committee in 2000 [6]

By 2016 the structure of the State Tax Committee has been further improved and has the following appearance: 


\begin{tabular}{|c|c|c|c|c|c|c|}
\hline \multirow{4}{*}{ Impact Factor: } & ISRA (India) & $=3.117$ & SIS (USA) & $=0.912$ & ICV (Poland) & $=6.630$ \\
\hline & ISI (Dubai, UAE & $=0.829$ & РИНЦ (Russia & $=0.156$ & PIF (India) & $=1.940$ \\
\hline & GIF (Australia) & $=0.564$ & ESJI (KZ) & $=8.716$ & IBI (India) & $=4.260$ \\
\hline & JIF & $=1.500$ & SJIF (Morocco & $=5.667$ & OAJI (USA) & $=0.350$ \\
\hline
\end{tabular}

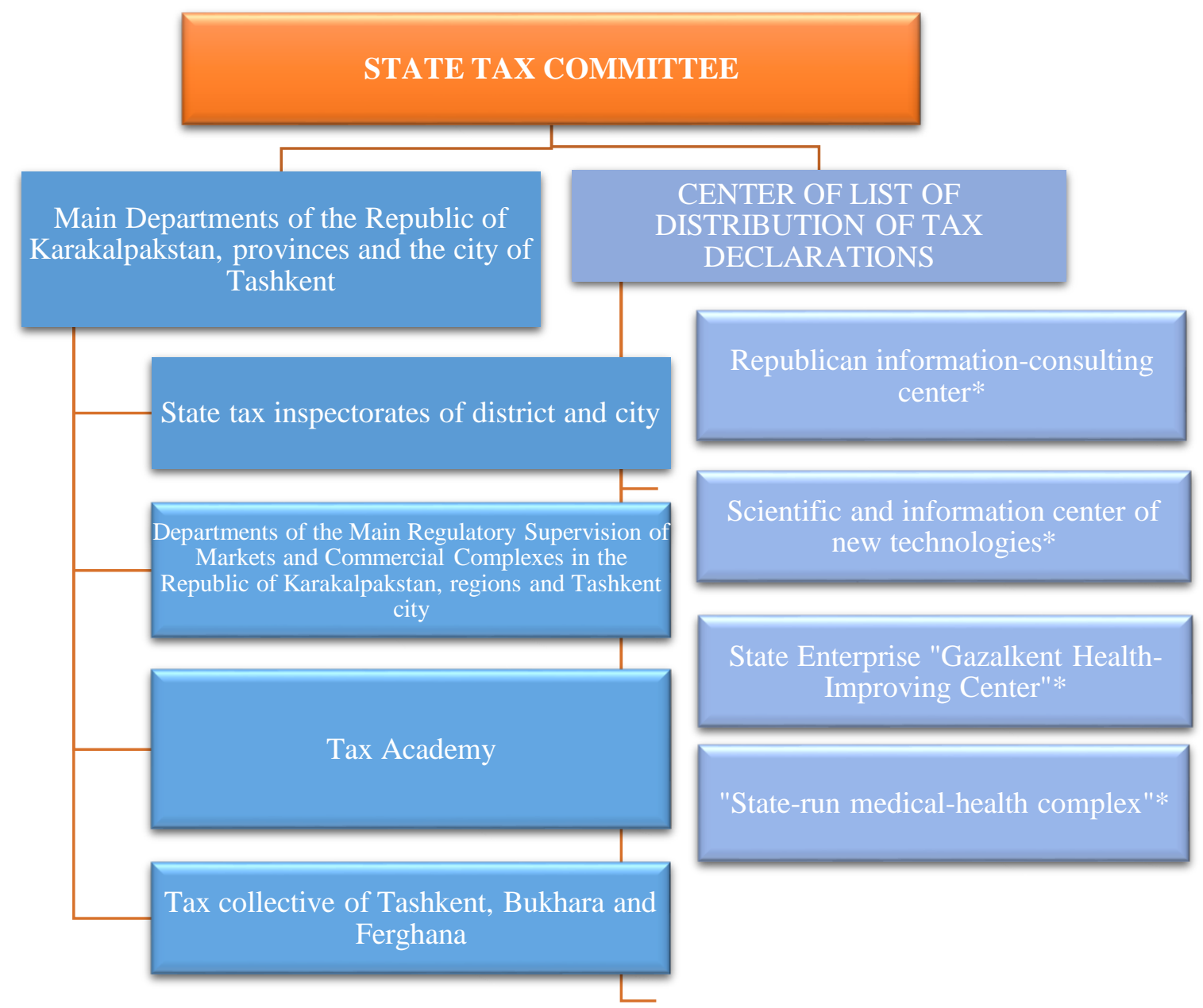

Fig.2. Structure of the State Tax Committee in 2016 [6]

The Decree of the President of the Republic of Uzbekistan Shavkat Mirziyayev of July 18, 2017 "On radical improvement of tax administrations, measures on increasing taxes and other obligatory payments" was adopted. In line with this decree, special attention has been paid to the issues of developing a new Tax Code and Tax Concept for the purpose of improving the taxation system. Also, according to the Resolution of the Cabinet of Ministers № 3168 of August 1, 2017 "dOn Measures for Further Improvement of the Activities of the State Tax Service", the structure of the State Tax Service has been revised and approved.[11] 


\begin{tabular}{|c|c|c|c|c|c|c|}
\hline \multirow{4}{*}{ Impact Factor: } & ISRA (India) & $=3.117$ & SIS (USA) & $=0.912$ & ICV (Poland) & $=6.630$ \\
\hline & ISI (Dubai, UAE & $=0.829$ & РИНЦ (Russia & $=0.156$ & PIF (India) & $=1.940$ \\
\hline & GIF (Australia) & $=0.564$ & ESJI (KZ) & $=8.716$ & IBI (India) & $=4.260$ \\
\hline & JIF & $=1.500$ & SJIF (Morocco & $=5.667$ & OAJI (USA) & $=0.350$ \\
\hline
\end{tabular}

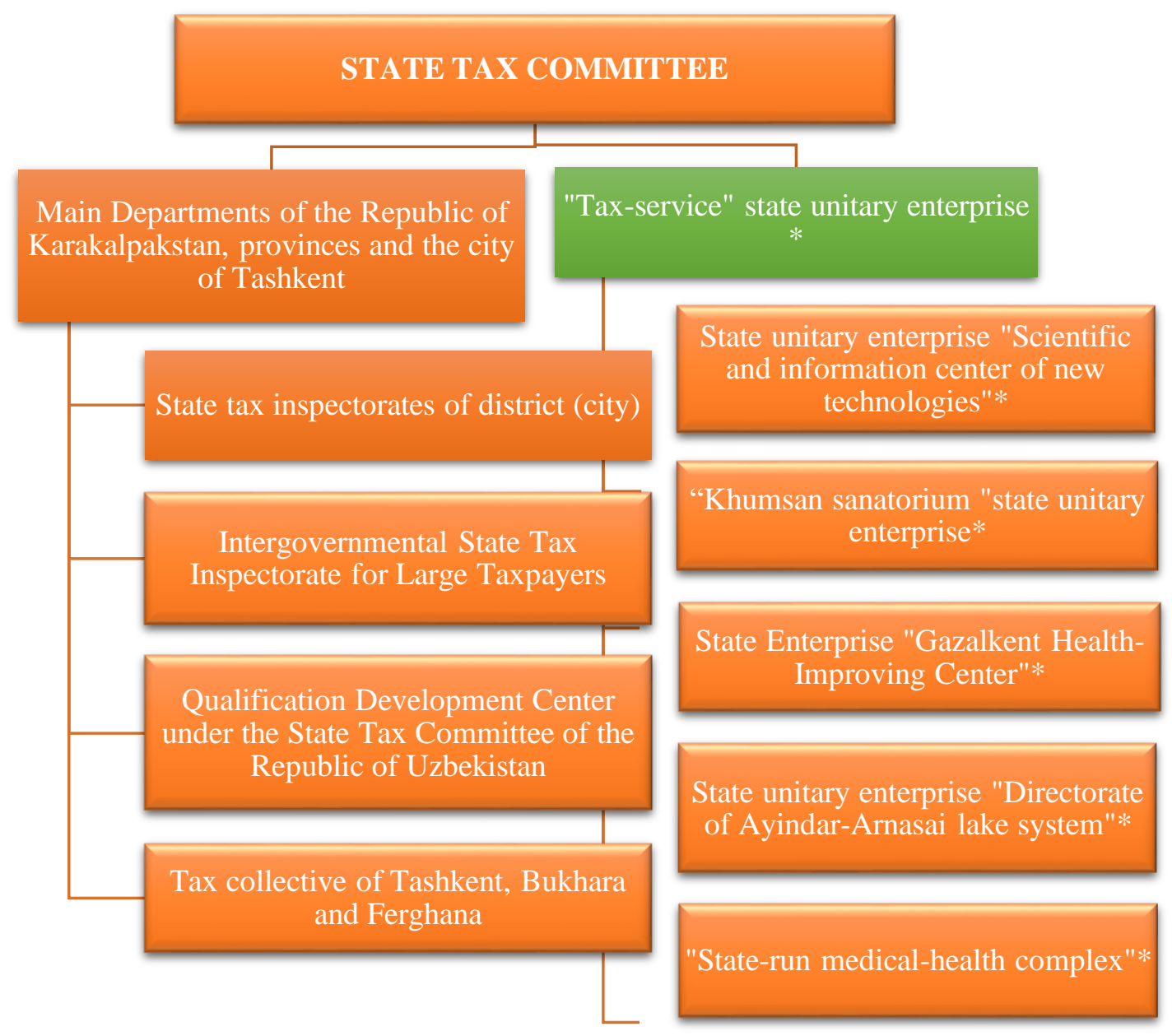

Fig.3. Structure of the State Tax Committee in $2018[7,8]$

Comparing and analyzing the structural subdivisions of the State Tax Committee, it has been significantly improved compared to the years of independence. Today, the State Tax Committee of the Republic of Uzbekistan in 2016 has the following structure:

- The activities of the Main Department for Control of Markets and Commodity Complexes in the Republic of Karakalpakstan, regions and the city of Tashkent have been changed to the work of the interregional State Tax Inspectorate with large taxpayers.

- The Tax Academy was liquidated and transformed into a Qualification Center under the State Tax Committee of the Republic of Uzbekistan.

- If the majority of the Committee's affiliated enterprises had established state-owned centers, now the state unitary enterprises would function. As a result, we can see reforms in the work of the committee, the effectiveness of the taxation staff, overcoming taxpayers, and increasing the knowledge of tax officials. The State Tax Committee of the Republic of Uzbekistan now has 200 State Tax Inspections. The total number of employees of the State Tax Service is 11890 , out of which 5984 are employees working with economic entities. The number of registered taxpayers is 619958 in 2017, and their number is 409449 . Of these, the number of small businesses (dekhkans and private farms) was 242379 , and the number of individual entrepreneurs was 280960. [9-10]

The following table shows the last 6 years: 


\begin{tabular}{|c|c|c|c|c|c|c|}
\hline \multirow{4}{*}{ Impact Factor: } & ISRA (India) & $=3.117$ & SIS (USA) & $=0.912$ & ICV (Poland) & $=6.630$ \\
\hline & ISI (Dubai, UAE & $=0.829$ & РИНЦ (Russia & $=0.156$ & PIF (India) & $=1.940$ \\
\hline & GIF (Australia) & $=0.564$ & ESJI (KZ) & $=8.716$ & IBI (India) & $=4.260$ \\
\hline & JIF & $=1.500$ & SJIF (Morocco & $=5.667$ & OAJI (USA) & $=0.350$ \\
\hline
\end{tabular}

Table 1. Information on employees of the State Tax Service

\begin{tabular}{|c|c|c|c|c|c|c|}
\hline & 2012 y. & 2013 у. & $2014 \mathrm{y}$ & $2015 \mathrm{y}$ & $2016 \mathrm{y}$ & 2017 y. \\
\hline Number of STSs & 194 & 193 & 193 & 193 & 193 & 200 \\
\hline By province & 12186 & 12172 & 12172 & 12172 & 12172 & 12133 \\
\hline Actual number (number) & 11939 & 12002 & 11858 & 12007 & 11732 & 11890 \\
\hline In $\%$ & 98,0 & 93,9 & 97,4 & 98,6 & 96,4 & 98,0 \\
\hline These are empty spaces & 247 & 170 & 314 & 208 & 440 & 243 \\
\hline $\begin{array}{l}\text { The number of employees } \\
\text { working with legal entities is as } \\
\text { follows }\end{array}$ & 6418 & 6443 & 6443 & 6399 & 5796 & 6072 \\
\hline Actual number of employees & 6296 & 6376 & 6310 & 6360 & 5644 & 5984 \\
\hline $\begin{array}{l}\text { The number of staff working } \\
\text { with individuals is by state }\end{array}$ & 4875 & 5122 & 5122 & 4789 & 2926 & 3158 \\
\hline Actual number of employees & 4870 & 5117 & 5081 & 4782 & 2844 & 3125 \\
\hline
\end{tabular}

Source: The author has been independently created on the basis of the comparison table of the main indices for 20122017.

Table 2. Information on undertakings

\begin{tabular}{|c|c|c|c|c|c|c|}
\hline & $\mathbf{2 0 1 2}$ й. & $\mathbf{2 0 1 3}$ й. & $\mathbf{2 0 1 4}$ й. & $\mathbf{2 0 1 5}$ й. & $\mathbf{2 0 1 6}$ й. & $\mathbf{2 0 1 7}$ й. \\
\hline Total registered legal entities & 551936 & 555457 & 561149 & 586773 & 616720 & 619958 \\
\hline Actual number of users & 283798 & 287730 & 303122 & 329487 & 365683 & 409449 \\
\hline $\begin{array}{c}\text { Number of Small Businesses } \\
\text { (without dekkhan and farms) }\end{array}$ & 208044 & 213516 & 221140 & 225998 & 233292 & 242379 \\
\hline $\begin{array}{c}\text { Activities } \\
\text { Total registered individual } \\
\text { entrepreneurs }\end{array}$ & 185559 & 202499 & 227646 & 251795 & 274975 & 280960 \\
\hline & 136845 & 158849 & 161311 & 161702 & 185988 & 182521 \\
\hline Activities & & & & & & \\
\hline
\end{tabular}

Source: The author has been independently created on the basis of the comparison table of the main indices for 20122017. 


\begin{tabular}{|c|c|c|c|c|c|c|}
\hline \multirow{4}{*}{ Impact Factor: } & ISRA (India) & $=3.117$ & SIS (USA) & $=0.912$ & ICV (Poland) & $=6.630$ \\
\hline & ISI (Dubai, UAE & $=0.829$ & РИНЦ (Russia & $=0.156$ & PIF (India) & $=1.940$ \\
\hline & GIF (Australia) & $=0.564$ & ESJI (KZ) & $=8.716$ & IBI (India) & $=4.260$ \\
\hline & JIF & $=1.500$ & SJIF (Morocco & $=5.667$ & OAJI (USA) & $=0.350$ \\
\hline
\end{tabular}

Table 3. Information about taxpayer physical persons

\begin{tabular}{|l|c|c|c|c|c|c|}
\hline & $\mathbf{2 0 1 2}$ й. & $\mathbf{2 0 1 3}$ й. & $\mathbf{2 0 1 4}$ й. & $\mathbf{2 0 1 5}$ й. & $\mathbf{2 0 1 6}$ й. & $\mathbf{2 0 1 7}$ й. \\
\hline Income tax & 4845053 & 5607874 & 6218163 & 6567004 & 5280156 & 5675191 \\
\hline Property tax & 4793606 & 4920365 & 5038206 & 5107023 & 5198671 & 5341710 \\
\hline Land tax & 4110262 & 4266130 & 4371523 & 4442979 & 4521320 & 4656635 \\
\hline Total: & 13748921 & 14794369 & 15627892 & 16117006 & 15000147 & 15673536 \\
\hline
\end{tabular}

Source: The author has been independently created on the basis of the comparison table of the main indices for 20122017.

Based on these tables, individuals and legal entities have been calculated individually to study taxpayer workloads of each Tax Officer. At the same time, we can see the following figures by years, including taxpayers, by number of tax inspectors.
If you pay attention to the tax burden of each tax officer, in 2012 there was an average of 87.7 taxpayer legal entities to each taxpayer dealing with business entities, which is forecast to be 103.6 in 2017 was created.

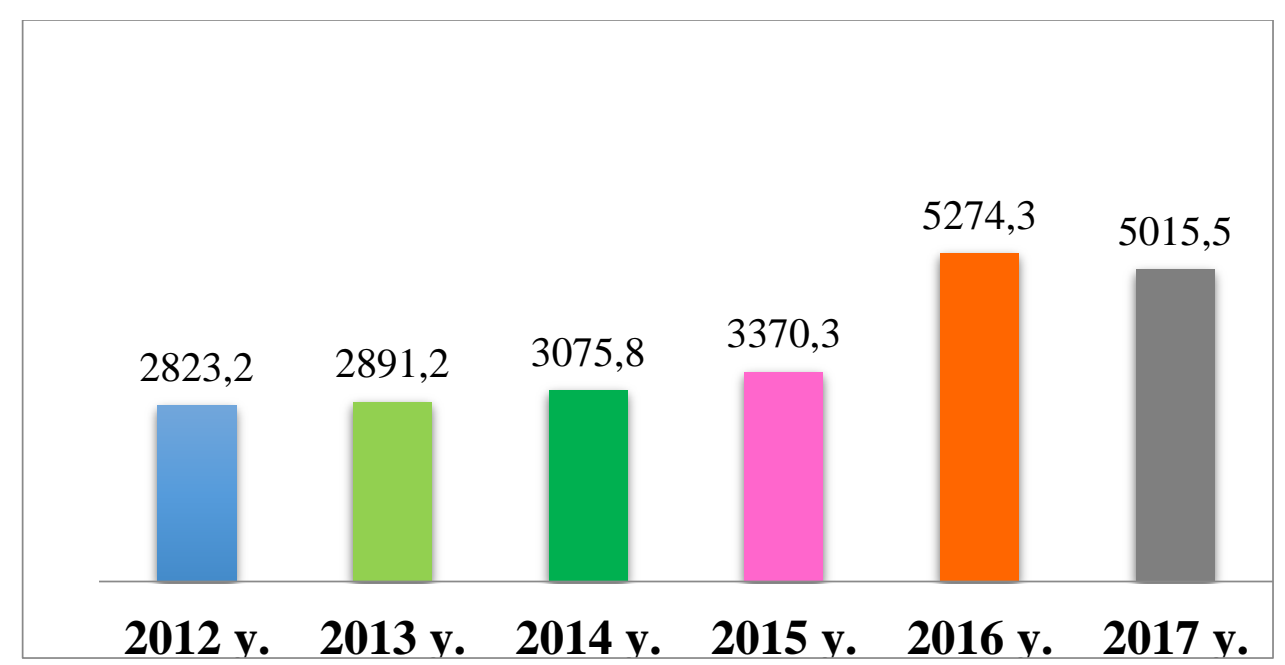

Fig.4. Work load per employee of each Tax Service working with individuals

If we pay attention to the tax burden on each tax officer working with taxpayers in tax offices, in 2012 we will pay 2823.2 for a tax officer, and by 2015 3370.3 registered taxpayers, service is required. However, we can observe a sharp increase in this indicator in recent years. Because some of the employees of the tax office of the government working with individuals have joined the Mandatory Execution Bureau (MIB).

These analyzes show that the taxpayer's workload is increasing, and this, in turn, should be focused on raising the level of responsibility and knowledge of taxpayers and focusing on increasing the efficiency of each employee in terms of division of labor.

The above figures testify to the fact that the most important task, such as increasing the control over the effectiveness of the tax service employees, reducing the workload and increasing their knowledge, skills and qualifications is not fully solved. This is one of the pressing issues of improving the mechanism of effective staffing in the tax system.

We can not say that their problems, such as their knowledge, experience and skills, their ability to do business, and even their lack of employment, still have an alternative solution.

In line with the above information and conclusions, we would like to make the following suggestions to improve the efficiency of the tax service employees:

1. Determine the ways to improve the field knowledge to increase the effectiveness of the Tax Service employees' network departments;

2. Identify the ways in which each taxpayer will be able to work effectively studying the workload based on his / her duties;

3. Organization of uniform organization of labor productivity of all tax service employees;

4. Studying the knowledge and skills of the Tax Service employees on information technology and computer skills, we can think of working out ways to 


\begin{tabular}{|c|c|c|c|c|c|c|}
\hline \multirow{4}{*}{ Impact Factor: } & ISRA (India) & $=\mathbf{3 . 1 1 7}$ & SIS (USA) & $=0.912$ & ICV (Poland) & $=6.630$ \\
\hline & ISI (Dubai, UAE & $=0.829$ & РИНЦ (Russia & $=0.156$ & PIF (India) & $=1.940$ \\
\hline & GIF (Australia) & $=0.564$ & ESJI (KZ) & $=8.716$ & IBI (India) & $=4.260$ \\
\hline & JIF & $=1.500$ & SJIF (Morocco & $=5.667$ & OAJI (USA) & $=0.350$ \\
\hline
\end{tabular}

improve the effectiveness of their work and their practical application.

\section{References:}

1. Mirziyoev, S. M. (2017, January 16). Critical analysis, strict disciplinary discipline and personal responsibility - should be a daily rule for each leader's activity. Halq suzi.

2. Mirziyoev, S. (2017). The Decree of the President of the Republic of Uzbekistan "On the Strategy for the Further Development of the Republic of Uzbekistan". (p.112). Huquq.

3. Yahyoev, Q. (2000). Taxation theory and practice. (p.38). Tashkent: Center for Science and Technology.

4. Tolakov, U., \& Makhmudov, O. (2013). Basis of taxation. Educational manual. (p.19). Termiz.

5. Jo'raev, A., Mirzaev, F. (2014). Tax system and its improvement. Lecture texts. SQS Tax Academy. (p.6). Tashkent.

6. (2000). Annex №1 to the Resolution of the Cabinet of Ministers of March 13, 2000 No 87.
7. Ibragimov, I. U., \& Tursunov, B. O. (2017). Enhancement the mechanism of analyzing of the methodological principles for the development and improvement of methods of assessment. Aydit, № 4, 11-13.

8. Tursunov, B. O. (2017). The main directions of support of small business in Uzbekistan and foreign experience of development of entrepreneurship. Audit, No. 6, 34-38.

9. (n.d.). Retrieved 2019, from https://soliq.uz/uz/about/soliq_organlarining tar kibiy tuzilmasi/qomita tarkibiy tuzilmasi/2016

10. (n.d.). Retrieved 2019, from https://soliq.uz/uz/about/soliq_organlarining_tar kibiy tuzilmasi/qomita tarkibiy tuzilmasi/2018

11. (n.d.). Retrieved 2019, from www.norma.uz 